JIKAP PGSD: Jurnal Ilmiah Ilmu Kependidikan

Vol,3. No,3. Tahun 2019

e-ISSN: 2597-4440 dan p-ISSN: 2597-4424

This work is licensed under a Creative Commons Attribution

4.0 International License

\title{
Analisis Kemampuan Berpikir Kreatif Mahasiswa PGSD Dalam Mendesain Soal Tes Bentuk Uraian Untuk Meningkatkan Soft Skills Mahasiswa
}

\author{
Susanti Faipri Selegi \\ Universitas PGRI Palembang \\ Email: susantifaipriselegi@gmail.com
}

\begin{abstract}
Abstrak. Tujuan penelitian ini adalah untuk mengetahui kemampuan berpikir kreatif mahasiswa PGSD dalam mendesain soal tes bentuk uraian untuk meningkatkan soft skills mahasiswa. Subjek penelitian ini adalah mahasiswa semester 4 yang berjumlah 45 orang. Metode dalam penelitian ini adalah kualitatif dengan Teknik pengumpulan data melalui tes dan dokumentasi. Hasil yang lain menunjukkan 53,3\% dari 45 mahasiswa memperoleh nilai pada kategori baik. Mahasiswa mampu mengelaborasi soal yang dibuat dengan mengembangkan kreativitas melalui media gambar, sehingga mudah dipahami siswa. Soal tes bentuk uraian yang dibuat lebih bervariatif dan disesuaikan dengan level kognitifnya. Selanjutnya, 8,88\% dari 45 mahasiswa memperoleh nilai pada kategori cukup dan 2,22\% pada kategori kurang. Hal ini disebabkan soal tes yang didesain belum mampu mengembangkan materi dengan baik, baik dari kisi-kisi maupun pedoman penskoran yang dibuat. Secara keseluruhan nilai rata-rata yang diperoleh adalah 77,42 dengan kategori baik. Dengan demikian, kemampuan berpikir kreatif mahasiswa fluency (kelancaran), flexibility (keluwesan), originality (keaslian), dan elaboration (keterincian) dapat meningkatkan soft skills mahasiswa dalam mendesain soal tes bentuk uraian kelas V (lima) SD.
\end{abstract}

Kata kunci: kemampuan berpikir kreatif, tes uraian, soft skills

\begin{abstract}
The purpose of this research was to know creative thinking skills of PGSD's students to design the essay test to increase student's soft skills. Subject of research are students in 4 semester that consist of 45 students. Method of this research is qualitative research with date collecting technique by test and documentation. The result of research show that 53,3\% of 45 students achieved the good score. The students could be able elaborated the essay test through the creativity using by picture in order to student in elementary school understand it. The essay test which had been made more creative and adjusted cognitive level. Furthermore, 8,88\% of 45 students achieved the enough categories and 2,22\% achieved the less category. This is due to the essay test not being able to develop the material properly, both from grids and scoring guidelines. Overall the average value obtained is $77,42 \%$ in the good category. Thus, students' creative thinking skills such as fluency, flexibility, originality, and elaboration can improve students' soft skills in designing the essay test in $5^{\text {th }}$ grade elementary school.
\end{abstract}

Keywords: creative thinking skills, the essay test, soft skills 


\section{PENDAHULUAN}

Pendidikan merupakan hal yang penting dalam meningkatkan kualitas seseorang, melalui pendidikan kita dapat mengembangkan kemampuan yang dimiliki menjadi suatu karya yang bermanfaat bagi dunia pendidikan. Undangundang nomor 20 tahun 2003 menjelaskan yang dimaksud dengan pendidikan adalah usaha sadar dan terencana untuk mewujudkan suasana belajar dan proses pembelajaran agar peserta didik secara aktif mengembangkan potensi dirinya untuk memiliki kekuatan spritual keagamaan, pengendalian diri, kepribadian, kecerdasan, akhlak mulia, serta keterampilan yang diperlukan dirinya, masyarakat, bangsa dan negara.

Undang-undang nomor 32 tahun 2013 tentang system pendidikan nasional menyebutkan bahwa kurikulum adalah seperangkat rencana dan pengaturan mengenai tujuan, isi, dan bahan pelajaran serta cara yang digunakan sebagai pedoman penyelenggaraan kegiatan pembelajaran untuk mencapai tujuan pendidikan tertentu. Untuk melaksanakan pendidikan yang bermutu diperlukan pendidik yang berkualitas. Pendidik yang dimaksud adalah tenaga kependidikan yang berkualifikasi sebagai guru, dosen, konselor, pamong belajar, widyaiswara, tuto, instruktur, fasilitator, dan sebutan lain yang sesuai dengan kekhususannya, serta berpartisipasi dalam menyelenggarakan pendidikan. Berdasarkan pengertian tersebut dapat diartikan bahwa satuan pendidikan atau perguruan tinggi diharapkan mampu menghasilkan calon-calon pendidik yang siap untuk menerapkan ilmu yang dimilikinya dalam dunia pendidikan.

Pelaksanaan pendidikan tidak dapat dipisahkan dari proses pembelajaran dan evaluasi. Pembelajaran dapat diartikan sebagai proses interaksi peserta didik dengan pendidik dan sumber belajar pada suatu lingkungan belajar, sedangkan evaluasi pendidikan diartikan sebagai kegiatan pengendalian, penjaminan, dan penetapan mutu pendidikan terhadap berbagai komponen pendidikan pada jalur, jenjang, dan jenis pendidikan sebagai bentuk pertanggung jawaban penyelenggaraan pendidikan.

Untuk memenuhi ketentuan tersebut salah satu kemampuan yang penting untuk dikembangkan pada mahasiswa adalah kemampuan berpikir tingkat tinggi yaitu kemampuan berpikir kritis dan berpikir kreatif. Hal ini disebabkan lemahnya mahasiswa dalam mengembangkan kreativitasnya, sehingga menjadi hal yang sangat penting untuk diperhatikan mengingat kompleksnya permasalahan kehidupan dan tantangan dimasa depan. Purwanto dalam (Yuli Ifana Sari, 2015) menjelaskan bahwa mahasiswa diharapkan lebih aktif dan kreatif mengkonstruksi pengalaman pembelajaran. Mahasiswa tidak hanya menerima informasi yang diperoleh dari orang lain namun mampu berkreasi (mencipta/membuat) segala sesuatu yang relevan dengan pengembangan pengetahuan. Mahasiswa diharapkan dapat menjadi problem solver (memecahkan masalah), self-motivation (mempunyai motivasi diri), dan personal quality (kualitas pribadi).

Hasil penelitian Imam Gunawan (2014) menunjukkan bahwa terdapat hubungan yang signifikasn pada variable kemampuan berpikir kreatif dan kritis terhadap prestasi belajar mahasiswa. Besarnya sumbangan efektif variable kemampuan berpikir kreatif adalah 20,13\% dan sumbangan efektif variable kemampuan berpikir kritis adalah $21,53 \%$ terhadap prestasi. Hasil penelitian lain menunjukkan bahwa Higher Order Thinking Skills (HOTS) melalui Creative Problem Solving (CPS) dapat digunakan dalam meningkatkan kemampuan kognitif mahasiswa (Selegi, 2019). Sementara itu, hasil penelitian Anita (2017) menunjukkan bahwa mahasiswa memiliki kemampuan untuk berpikir tingkat tinggi sesuai dengan jenjang usianya. Hasil penelitian tersebut diperjelas oleh Munandar dalam (Hidayat, 2012) mengemukakan aspekaspek yang digunakan untuk mengukur kreativitas yaitu kelancaran (fluency), keluwesan (flexibility), keaslian (originality), dan keterincian (elaboration). Keempat aspek tersebut dapat dijadikan tolak ukur dalam menentukan kemampuan berpikir kreatif mahasiswa. Melalui mata kuliah evaluasi pembelajaran mahasiswa diarahkan untuk meningkatkan kemampuan kognitifnya dalam membuat/mengkonstruksi tes jenis objektif Sekolah Dasar (SD). Tujuannya adalah untuk mengdeskripsikan tingkat kemampuan dan kreativitas mahasiswa PGSD dalam mendesain soal tes.

Menurut Piaw dalam (Rezaei Kargar, 2013) "The process of creative thinking imparts the ability to generate the new ideas..." pernyataan tersebut dapat diartikan bahwa pentingnya proses berpikir kreatif untuk menghasilkan ide-ide baru dalam upaya meningkatkan kemampuan analisis dan kreativitas mahasiswa baik secara logika (thinking) maupun tindakan (action). J.Sternberg (2010) kreativitas membutuhkan enam sumber 
yang saling berhubungan yaitu kemampuan intelektual, pengetahuan, gaya berpikir, kepribadian, motivasi dan lingkungan. Lebih lanjut, Amabile dalam (Vidal, 2010) mengemukakan bahwa kreativitas pada masingmasing individu mempunyai tiga komponen, yaitu keahlian (expertise), kemampuan berpikir kreatif (creative-thinking skills), dan motivasi (motivation). Berdasarkan pengertian tersebut, kemampuan berpikir kreatif dapat dimanfaatkan sebagai pengetahuan, motivasi, keahlian, dan menjadi gaya berpikir seseorang yang dipengaruhi dari lingkungan.

Sehubungan dengan kreativitas tersebut mahasiswa membutuhkan penguatan soft skills agar mahasiswa sebagai calon guru memiliki pengetahuan yang baik. Hasil penelitian Rosana (2014) menjelaskan bahwa menumbuhkan soft skills pada diri mahasiswa melalui berbagai kegaitan belajar yang terjadi di kelas, lingkungan kampus, dan tugas-tugas diluar kampus. Pengembangan soft skills ini berpengaruh secara signifikan terhadap peningkatan hasil belajar mahasiswa baik secara proses maupun produk yang diambil datanya melalui tes. Lebih lanjut, Shaheen Majid (2012) menjelaskan pentingnya soft skills untuk sukses pendidikan dan karir, yaitu "the top five important soft skills identified by the students were: teamwork and collaboration, decision-making, problemsolving, time management and critical thinking skills." Lima hal penting soft skills, yaitu adanya tim kerja dan mampu berkolaborasi, membuat keputusan, memecahkan masalah, dan kemampuan manajemen waktu dan kemampuan berpikir kritis. Kelima kemampuan tersebut saling berelaborasi untuk meningkatkan kemampuan mahasiswa PGSD sebagai calon guru, terutama dalam mendesain soal tes bentuk uraian.

Peningkatan mutu Pendidikan tidak dapat dipisahkan dari pelaksanaan evaluasi pendidikan. Evaluasi menurut Stufflebeam dalam Victor (2009) "evaluation as a process of delineating, obtaining, reporting, and applying descriptive and judgment information about some object merit, worth, probity, and significance." Evaluasi sebagai proses menggambarkan, memperoleh, melaporkan, dan menerapkan informasi deskriptif dan penilaian tentang beberapa objek, nilai, kejujuran, dan signifikansi objek. Pengertian ini menjelaskan bahwa evaluasi tidak hanya mengumpulkan informasi sebagai kesimpulan tentang kualitas program, produk, atau perencanaan akan tetapi dihubungkan dengan penilaian. Peraturan Menteri Pendidikan Nasional nomor 20 tahun 2007 tentang Standar Penilaian Pendidikan, menjelaskan bahwa standar penilaian pendidikan adalah standar nasional pendidikan yang berkaitan dengan mekanisme, prosedur, dan instrument penilaian hasil belajar peserta didik. Penilaian dapat dilakukan melalui tes dan non-test. Penilaian melalui tes dapat dikategorikan menjadi tes tertulis, tes lisan, tes yang berhubungan dengan praktik siswa dan lain-lain. Sedangkan non-test meliputi penilaian instrument sikap, instrument kuesioner/angket, dan pengamatan lainnya yang mendukung penilaian hasil belajar siswa.

Evaluasi keberhasilan belajar siswa dapat dilihat berdasarkan tes formatif maupun tes sumatif. Pembuatan perangkat tes untuk kepentingan evaluasi harus didasarkan pada standar sehingga hasil yang diperoleh dapat dipertanggunjawabkan. Masrun dalam (Suryani, 2017) menjelaskan gambaran tentang baiknya suatu alat ukur tercermin pada karakteristik perangkat soal itu sendiri. Karakteristik yang dimaksud adalah ciri-ciri tes yang baik, yaitu validitas, reliabilitas, tingkat kesukaran dan daya beda. Adapun jenis-jenis tes terbagi menjadi dua, yaitu tes objektif dan tes subjektif. Tes objektif adalah tes yang dilakukan secara objektif dan pilihan jawaban sudah tersedia, siswa hanya menentukan pilihan jawaban yang paling benar. Adapun jenis tes objektif yaitu pilihan ganda (multiple choice test), true-false (benar-salah), matching test (tes menjodohkan), dan complement test (tes melengkapi kalimat). Tes subjektif adalah tes yang dilakukan secara subjektif, penilaiannya dilakukan dengan dasar pertimbangan tertentu (subjektif) seseorang. Adapun jenis tes subjektif, yaitu tes uraian bebas dan terbatas. Menurut Kemendikbud (2017) berdasarkan penskorannya soal bentuk uraian diklasifikasikan menjadi uraian objektif dan uraian non-objektif. Soal bentuk uraian objektif adalah rumusan soal atau pertanyaan yang menuntut sehimpunan jawaban dengan pengertian/konsep tertentu sehingga penskorannya dapat dilakukan secara objektif. Soal bentuk uraian nonobjektif adalah rumusan soal yang menuntut sehimpunan jawaban berupa pengertian/konsep menurut pendapat masingmasing peserta didik sehingga penskorannya sukar dilakukan secara objektif (penskorannya dapat mengandung unsur subjektivitas).

Krathwohl dan Anderson dalam (Imam Gunawan, 2014) menjelaskan ranah kognitif siswa yang terdiri dari mengingat (recalling), 
mengerti/memahami (understand), mengaplikasikan (apply), menganalisis (analyse), mengevaluasi (evaluate), dan menciptakan (create). Taksonomi bloom pada ranah kognitif tersebut menjadi dasar yang dapat digunakan dalam mendesain soal tes. Sebagai calon pendidik sudah seharusnya memiliki pengetahuan dalam mendesain instrumen tes yang baik. Hal yang perlu diperhatikan sebelum membuat soal tes bentuk uraian, mahasiswa perlu membuat kisikisi tes. Kisi-kisi adalah suatu format atau matriks yang memuat informasi yang dapat dijadikan sebagai pedoman untuk menulis soal atau merakit soal. Kisi-kisi disusun berdasarkan tujuan penggunaan tes (Kemdikbud, 2017). Adapun syarat penyusunan kisi-kisi tes, yaitu (1) mewakiliki isi kurikulum yang akan diujikan, (2) komponen-komponen rinci, jelas, dan mudah dipahami, (3) indicator soal harus jelas dan dapat dibuat soalnya sesuai dengan bentuk soal yang telah ditetapkan. Proses yang dilakukan sebelum mendesain soal tes mahasiswa harus memahami kompetensi dasar, materi, dan indikator. Berikut diagram yang menjelaskan proses pembuatan kisi-kisi.

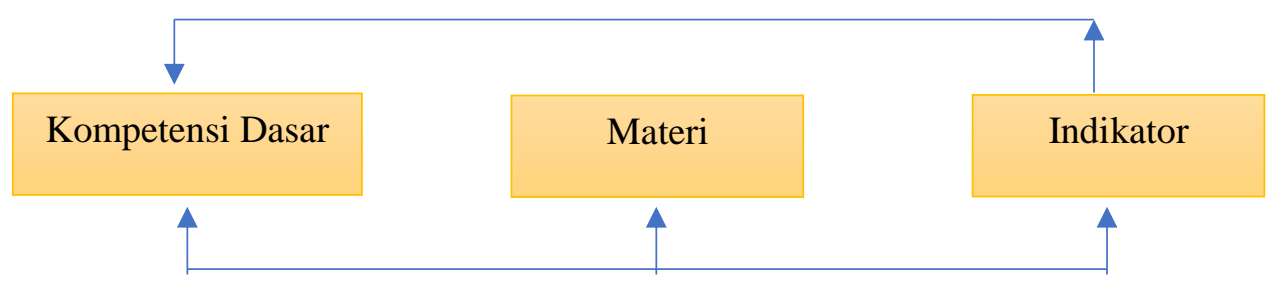

Sumber: kemendikbud, 2017

Gambar 1. Diagram Proses Penjabaran KD menjadi indikator

Diagram di atas menunjukkan bahwa untuk penyusun kisi-kisi menjadi indikator perlu melalui langkah-langkah berikut: 1) memilih KD yang akan diukur; 2) menentukan materi; 3) membuat indikator yang mengacu pada KD dengan memperhatikan materi/konsep yang dipilih. Dalam hal ini mahasiswa menentukan KD berdasarkan kelas yaitu kelas 5. Siswa pada kelas tinggi ini termasuk anak yang memiliki potensi sehingga akan berkembang secara optimal. Pembelajaran di kelas tinggi dilakukan berdasarkan RPP yang dibuat oleh guru. Proses pembelajaran harus didesain oleh guru sehingga kemampuan siswa dapat meningkat, bahan ajar, proses belajar, dan system penilaian disesuaikan dengan tahap perkembangannya. Sementara itu, untuk mengembangkan KD diperlukan indicator ketercapaian, adapun kriteria indicator menurut Kemendikbud (2017) yaitu (1) memuat ciri-ciri KD yang akan diukur, (2) memuat kata kerja operasional yang dapat diukur (satu kata kerja operasional untuk soal pilihan ganda, satu atau lebih dari satu kata kerja operasional untuk soal uraian), (3) berkaitan dengan materi/konsep yang dipilih, (4) dapat dibuat soalnya sesuai dengan bentuk soal yang telah ditetapkan. Berikut ini contoh kisi-kisi penulisan soal SD.

Tabel 1: Kisi-kisi Penulisan Soal SD KISI-KISI PENULISAN SOAL

\begin{tabular}{|c|c|c|c|c|}
\hline \multicolumn{5}{|c|}{ KISI-KISI PENULISAN SOAL } \\
\hline \multirow{2}{*}{\multicolumn{2}{|c|}{$\begin{array}{l}\text { Jenjgan Pendidikan } \\
\text { Mata Pelajaran }\end{array}$}} & $/ \mathrm{MI}$ & Kurkulum & \\
\hline & & & Bentuk Soal & \\
\hline Kompetensi Dasar & Kelas & Materi & Indikator & $\begin{array}{c}\text { Nomor } \\
\text { Soal }\end{array}$ \\
\hline $\begin{array}{l}\text { Menganalisis hubungan } \\
\text { antar komponen ekosistem } \\
\text { dan jarring-jaring } \\
\text { makanan di lingkungan } \\
\text { sekitar }\end{array}$ & V & Ekosistem & $\begin{array}{l}\text { Disajikan gambar jarring-jaring } \\
\text { makanan pada ekosistem tertentu, } \\
\text { peserta didik dapat menentukan } \\
\text { komponen ekosistem yang memiliki } \\
\text { peran tertentu dan menjelaskan akibat } \\
\text { yang akan terjadi bila salah satu } \\
\text { komponenya mengalami kepunahan }\end{array}$ & 1 \\
\hline
\end{tabular}

Sumber: kemendikbud, 2017 
Kisi-kisi dikembangkan berdasarkan kompetensi dasar (KD) kelas V (lima) pada kelas tinggi dengan mata pelajaran IPA dengan materi ekosistem. Berdasarkan contoh kisi-kisi tersebut mahasiswa diharapkan dapat membuat kisi-kisi yang sama dengan mata pelajaran dan materi yang berbeda.

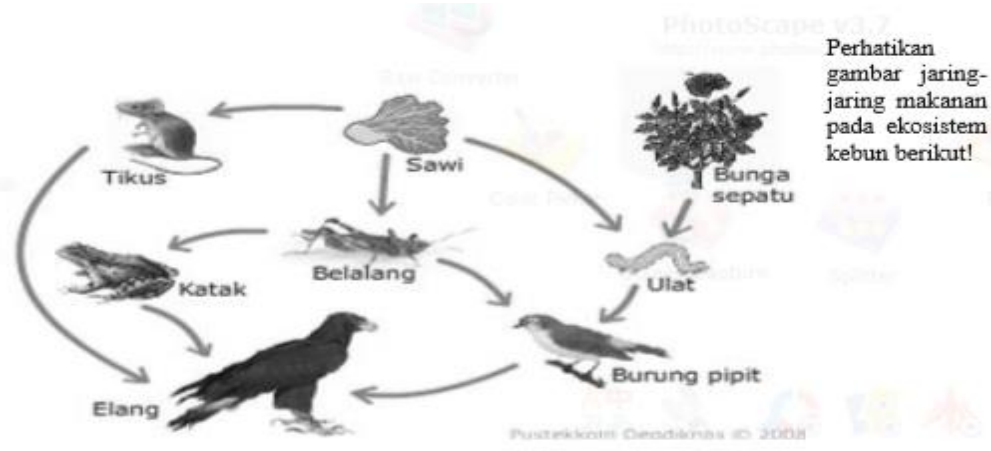

Sumber: kemendikbud, 2017

Gambar 2. Contoh Soal IPA Kelas V

Gambar di atas menunjukkan suatu ekosistem yang merupakan pengembangan dari kisi-kisi dan indicator yang dibuat sebelumnya. Melalui contoh gambar tersebut diharapkan mahasiswa mempunyai kreativitas dalam mendesain materi yang lebih menarik dan mudah dipahami siswa.

Tabel 2: Contoh Pedoman Penskoran

\section{No Kunci Jawaban} Skor

a Mahkluk hidup yang berperan sebagai:

Produsen : sawi dan bunga sepatu

Konsumen 1 : ulat, belalang, dan tikus

Konsumen 2 : katak dan burung pipit

Konsumen 3 : elang

b Makhluk hidup yang merupakan konsumen puncak adalah elang

1

Alasannya : tidak ada lagi yang memangsa elang pada jarring-jaring makanan di atas

1

c Akibat populasi belalang menurun adalah :

- Populasi katak akan menurun juga jumlahnya karena belalang makanan katak 1

- Populasi sawi akan naik jumlahnya karena elang makan sawi

Skor maksimum

1

Sumber: kemendikbud, 2017

Pedoman penskoran digunakan sebagai acuan dalam penilaian. Seorang calon guru seharusnya memiliki kompetensi (soft skills) yang baik salah satunya dengan mendesain rubrik penilaian seperti contoh di atas, sedangkan untuk bobot skor ditentukan berdasarkan tingkat kesukaran materi.

\section{METODE PENELITIAN}

Penelitian ini menggunakan metode kualitatif. Sugiyono (2012) metode kualitatif adalah metode penelitian yang berlandaskan pada filsafat postpositivime, digunakan untuk meneliti pada kondisi objek yang alamiah dimana peneliti sebagai instrumen kunci. Peneliti menggunakan pendekatan kualitatif didasarkan pada analisis kemampuan mahasiswa PGSD dalam mendesain soal tes bentuk uraian. Subjek penelitian adalah mahasiswa semester 4 (empat) Program Studi PGSD Universitas PGRI Palembang yang berjumlah 45 orang pada mata kuliah Evaluasi Pembelajaran. Teknik pengumpulan data menggunakan teknik test dan dokumentasi. Tes digunakan untuk mendeskripsikan kemampuan berpikir kreatif mahasiswa dalam mendesain soal tes bentuk uraian. Sedangkan teknik dokumentasi dilakukan dengan mengumpulkan instrument yang dibuat mahasiswa beserta dokumen pendukung lainnya. Kriteria penilaian yang digunakan sebagai berikut. 
JIKAP PGSD: Jurnal Ilmiah Ilmu Kependidikan

Tabel 3: Kriteria Penilaian

\begin{tabular}{cc}
\hline Kriteria Penilaian & Keterangan \\
\hline $\mathbf{8 5}-\mathbf{1 0 0}$ & Sangat baik \\
\hline $\mathbf{7 0}-\mathbf{8 4}$ & Baik \\
\hline $\mathbf{6 0}-\mathbf{6 9}$ & Cukup \\
\hline $\mathbf{5 1}-\mathbf{5 9}$ & Kurang \\
\hline $\mathbf{0}-\mathbf{5 0}$ & Sangat kurang \\
\hline
\end{tabular}

Untuk membuat suatu tes yang baik, maka dibuat kisi-kisi instrument tes bentuk uraian. Tes ini dilaksanakan pada tes formatif semester 4 mahasiswa PGSD. Tujuannya untuk melihat ketercapaian materi yang diberikan dengan tingkat kemampuan berpikir kreatif mahasiswa dalam mendesain soal tes SD. Adapun kisi-kisi instrument tes dapat dilihat pada tabel 4 di bawah ini.

Tabel 4: Kisi-kisi Instrumen Tes

\begin{tabular}{|c|c|c|}
\hline Aspek & Indikator & Skor \\
\hline kelancaran (fluency) & $\begin{array}{ll}\text { - } & \text { Mahasiswa dapat mendesain soal tes bentuk uraian } \\
\text { berdasarkan topik yang telah ditentukan } \\
\text { - } \\
\text { - } & \text { Mencetuskan banyak gagasan } \\
\end{array}$ & $0-25$ \\
\hline keluwesan (flexibility) & $\begin{array}{l}\text { - Mahasiswa dapat dengan mudah mengembangkan } \\
\text { kreativitasnya dalam mendesain soal tes bentuk uraian } \\
\text { - Menganalisis varaisi-varaisi gagasan atau jawaban suatu } \\
\text { pertanyaan } \\
\text { - Menyajikan suatu konsep dengan cara yang berbeda-beda }\end{array}$ & $0-25$ \\
\hline keaslian (originality) & $\begin{array}{l}\text { - Soal tes bentuk uraian yang dibuat merupakan hasil } \\
\text { originalitas mahasiswa } \\
\text { - Memberikan gagasan yang relative baru }\end{array}$ & $0-25$ \\
\hline keterincian (elaboration) & $\begin{array}{l}\text { - Soal tes bentuk uraian yang dibuat lebih bervariatif dan } \\
\text { disesuaikan dengan level kognitifnya } \\
\text { - } \\
\text { Menambahkan, menata atau memperinci suatu gagasan } \\
\text { sehingga meningkatkan kualitas gagasan }\end{array}$ & $0-25$ \\
\hline
\end{tabular}

Sumber: data primer 2019

Analisis data dalam penelitian ini menggunakan tiga tahapan yaitu (1) reduksi data, (2) penyajian data, dan (3) penarikan kesimpulan/verifikasi. Adapun keabsahan data menggunakan; (1) perpanjangan keikutsertaan, pada tahap ini peneliti melakukan penelitian langsung dilokasi penelitian. (2) Ketekunan pengamatan, peneliti secara konsisten menemukan hal-hal yang berhubungan dengan desain soal tes SD bentuk uraian. (3) Triangulasi sumber, dengan cara mengecek data yang diperoleh melalui sumber, kemudian data dianalisis sehingga menghasilkan suatu kesimpulan. (4) Pemeriksaan sejawat, dilakukan oleh dosen yang relevan dengan bidang ilmunya. (5) Mengadakan member check, tahapan ini dilakukan untuk mengecek kelengkapan data, analisis, penafsiran dan kesimpulan.

\section{HASIL DAN PEMBAHASAN}

Hasil penelitian analisis kemampuan berpikir kreatif mahasiswa PGSD dalam mendesain soal tes bentuk uraian dilaksanakan dengan menggunakan instrument tes dan dokumentasi. Adapun hasil instrument tes pada tabel 5 di bawah ini.

Tabel 5: Hasil Nilai Tes Mahasiswa dalam Mendesain Soal Tes SD Bentuk Uraian

\begin{tabular}{ccccc}
\hline No & \multicolumn{1}{c}{ Nilai } & Frekuensi & Persentase & Kategori \\
\hline $\mathbf{1}$ & $85-100$ & 16 & 35,5 & Sangat baik \\
\hline $\mathbf{2}$ & $70-84$ & 24 & 53,3 & Baik \\
\hline $\mathbf{3}$ & $60-69$ & 4 & 8.88 & Cukup \\
\hline $\mathbf{4}$ & $51-59$ & 1 & 2,22 & Kurang \\
\hline $\mathbf{5}$ & $0-50$ & 0 & 0 & Sangat Kurang \\
\hline & Jumlah & 45 & & \\
\hline
\end{tabular}

Hasil instrument tes menunjukkan bahwa $35,5 \%$ dari 45 mahasiswa mendapatkan nilai sangat baik. Hal ini dibuktikan dengan kelancaran (fluency) dan keluwesan (flexibilitas) mahasiswa 
dalam mendesain dan mengembangkan soal tes bentuk uraian berdasarkan kompotensi dasar (KD) yang telah ditentukan. Mahasiswa dapat mendesain soal tes bentuk uraian berdasarkan topik yang telah ditentukan, mengembangkan kreativitasnya melalui kisi-kisi dan pedoman penskoran yang dapat dikerjakan dengan cepat. Hasil yang lain menunjukkan $53,3 \%$ dari 45 mahasiswa memperoleh nilai pada kategori baik. Mahasiswa mampu mengelaborasi soal yang dibuat dengan mengembangkan kreativitas melalui media gambar, sehingga mudah dipahami siswa. Soal tes bentuk uraian yang dibuat lebih bervariatif dan disesuaikan dengan level kognitifnya dan kelasnya. Ini yang disebut originality concept, konsep dibuat dengan sumber yang jelas dan ide-ide yang kreatif. Selanjutnya, 8,88\% dari 45 mahasiswa memperoleh nilai pada kategori cukup dan 2,22\% pada kategori kurang. Hal ini disebabkan mahasiswa belum mampu mengembangkan originality, elaboration, flexibility, dan fluency, soal tes yang didesain belum mampu mengembangkan materi dengan baik, baik dari kisi-kisi maupun pedoman penskoran yang dibuat. Soal tes bentuk uraian yang dibuat tidak didasarkan pada ide/gagasan yang kreatif dan terkesan monoton. Secara keseluruhan nilai rata-rata yang diperoleh adalah 77,42 dengan kategori baik.

Sabandar dalam (Mona, 2015) berpikir kreatif adalah suatu kemmapuan berpikir yang berawal adanya kepekaan terhadap situasi yang sedang dihadapi, situasi tersebut terlihat atau teridentifikasi adanya masalah yang harus diselesaikan. Selain itu, ada unsur keaslian (originality) terhadap gagasan yang muncul dalam pikiran seseorang. Berdasarkan empat kemampuan berpikir kreatif, kemampuan berpikir lancar (fluency) ditunjukkan dari mahasiswa yang mampu memberikan banyak ide/gagasan untuk menyelesaikan soal tes dan mendesain dengan berbagai variasi, baik dari jenis soal maupun gambar-gambar yang dibuat untuk menarik siswa. Kemampuan elaboration ditunjukkan dengan kemampuan mahasiswa dalam menguraikan kompetensi dasar (KD) menjadi indikator, dan mengembangkan ide/gagasan yang sudah ada secara lebih detail dan mudah dipahami siswa. Berdasarkan keempat indicator kemampuan berpikir kreatif tersebut (fluency, flexibility, originality, dan elaboration) dapat digunakan sebagai acuan dalam mengembangkan kemampuan berpikir kreatif mahasiswa dengan memecahkan masalah melalui ide-ide kreatif dan bias dipertanggunjawabkan keasliannya.

Hasil penelitian di atas, diperkuat dengan teori yang dikemukakan Siswono dalam (Mona, 2015) berpikir kreatif mengisyaratkan ketekunan, disiplin pribadi, dan melibatkan aktivitasaktivitas mental seperti mengajukan pertanyaan, mempertimbangkan informasi-informasi baru dan ide-ide yang tidak biasa dengan suatu pikiran terbuka, membuat hubungan-hubungan, khususnya antara sesuatu yang serupa yang membangkitkan ide baru dan berbeda. Sehubungan dengan hal tersebut, upaya untuk meningkatkan kemampuan soft skills mahasiswa harus ditingkatkan lagi dengan lebih banyak latihan yang mengasah kemampuan berpikir kreatif. Oleh karena itu, pengembangan soft skills dimungkinkan dapat mengembangkan kepribadian, partisipasi dalam pembelajaran dan keberhasilan dalam pekerjaan. Shaheen Majid (2012) mengemukakan bahwa soft skills mengacu pada kepribadian, kualitas dan perilaku individu seperti komunikasi, problem-solving, self-motivation, decision-making, dan kemampuan time management.

\section{SIMPULAN DAN SARAN}

Berdasarkan hasil analisis dan pembahasan dapat disimpulkan bahwa kemampuan berpikir kreatif mahasiswa memiliki hasil yang baik. Fluency (kelancaran), flexibility (keluwesan), originality (keaslian), dan elaboration (keterincian) dapat dilakukan dengan saling melengkapi antar bagian. Mahasiswa dibutuhkan waktu yang banyak untuk lebih mengembangkan kemampuan yang mereka miliki menjadi hasil yang bermanfaat. Melalui kemampuan berpikir kreatif mampu meningkatkan soft skills mahasiswa dalam mendesain soal tes bentuk uraian kelas V (lima) SD. Adapun saran dalam penelitian ini adalah agar mahasiswa dalam setiap perkuliahannya dapat menggunakan kemampuan berpikir kreatifnya agar dapat mengembangkan kemampuan soft skills dengan lebih baik sebagai kompetensi yang harus dimiliki calon guru.

\section{DAFTAR RUJUKAN}

Anita, I. W. 2017. Implementasi Pembelajaran Berbasi Proyek untuk Menunmbukan Kemampuan Berpikir Kreatif Matematis Mahasiswa. JPPM. 10 (1): 125-131.

Hidayat, W. 2012. Meningkatkan Kemampuan Berpikir Kritis dan Kreatif Matematik Siswa SMA Melalui Pembelajaran 
JIKAP PGSD: Jurnal Ilmiah Ilmu Kependidikan

Kooperatif Think-Talk-Write (TTW). Prosiding Seminar Nasional Penelitian, Pendidikan dan Penerapan MIPA, Fakultas MIPA Universitas Negeri Yogyakarta.

Imam, G. S. N. 2014. Hubungan Kemampuan Berpikir Kreatif dan Kritis dengan Prestasi Belajar Mahasiswa Pada Mata Kuliah Konsep Sains II Prodi PGSD IKIP PGRI Madiun. Premiere Educandum, 4 (1): $10-40$.

Kemdikbud, B. 2017. Panduan Penulisan Soal SD/MI. Jakarta: Pusat Penilaian Pendidikan Badan Penelitian Dan Pengembangan Kementerian Pendidikan Dan Kebudayaan.

J.Sternberg, R. 2010. The Nature of Creativity. Creativity Research Journal, 87-98.

Mona, L. 2015. Pengembangan Instrumen Kemampuan Berpikir Kreatif Matematis Untuk Siswa SMP. Jurnal Matematika dan Pendidikan Matematika, 4 (1): 27 41.

Rezaei, K. F. A. 2013. TheEffect of Teaching Criticaland Creative Thinking Skills on theLocus of Control and Psychological Well-Being in Adolescents. Jurnal Procedia - Social and Behavioral Sciences, 51-56.

Rosana, J. P. 2014. Pengembangan Soft Skills Mahasiswa Program Kelas Internasional Melalui Pembelajaran Berbasis Konteks Untuk Meningkatkan Kualitas Proses Dan Hasil Belajar Mekanika. Jurnal Pendidikan IPA Indonesia, 12-21.

Selegi, S. F. 2019. Analisis Kemampuan Higher Order Thinking Skill(Hots) Melalui Creative Problem Solving(CPS) UntukMeningkatkanKemampuanKognit ifMahasiswa . Jurnal Swarnabhumi: Jurnal Geografi dan Pembelajaran Geografi, 4 (1): 24-34.

Shaheen M. Z. L. 2012. Importance of Soft Skills for Education and Career Success. International Journal for CrossDisciplinary Subjects in Education (IJCDSE), 2 (2): 1036-1042.

Sugiyono. 2012. Metode Penelitian Kuantitatif, Kualitatif, dan $R \&$ D. Cetakan ke-17. Bandung: Alfabeta.

Suryani, Y. E. 2017. Pemetaan Kualitas Empirik Soal Ujian Akhir Semester Pada Mata Pelajaran Bahasa Indonesia Sma Di Kabupaten Klaten . Jurnal Penelitian dan Evaluasi Pendidikan, 21 (2): 142-152.
Yuli, I. S. D. F. 2015. Pengaruh Model Pembelajaran Treffinger Terhadap Kemampuan Berpikir Kritis dan Kreatif Mahasiswa Universitas Kanjuruhan Malang. Jurnal Pendidikan

Vidal, R. V. 2010. Creative Problem Solving: An Applied University Course. Pesquisa Operacional, 30 (2): 405-426. 